Systematic Review

\title{
Effectiveness of Physical Exercise on the Glycemic Control of Type 2 Diabetes Mellitus Patients: A Systematic Review
}

\section{Yulia Kurniawati, Hurin'in Aisy Baridah, Made Dian Kusumawati and Irfan Wabula}

Faculty of Nursing, Universitas Airlangga, Surabaya, East Java, Indonesia

\begin{abstract}
Introduction: Type 2 diabetes mellitus (T2DM) is one of the main causes of increasing global health morbidity and mortality for diabetes cases. Increasing the glycemic control in patients with T2DM is not enough if it is only treated with anti-hyperglycemic drugs. Physical exercise is an activity that is planned, structured and carried out to improve health or physical fitness and it is an effective way to improve glycemic control. The aim of this study was to search and review the research on effectiveness of physical exercise on glycemic control in T2DM.
\end{abstract}

Methods: We searched the scientific literature on T2DM and physical exercise in the ScienceDirect, ProQuest, Scopus, Ebsco and Pubmed databases for original research studies and then we reviewed them systematically. Of the 1145 articles retrieved, 14 studies were obtained by the PRISMA (Preferred Reporting Items for Systematic Reviews and MetaAnalyses) method

Results: Aerobic physical exercise improved the glycemic control of T2DM and it was widely used and significant for glycemic control. The schedule of 3 times a week for 60 minutes per session over 2 months was widely used and significant when it came to reducing blood glucose and hemoglobin A1c (HbA1c).

Conclusion: This systematic review could be used as evidence when carrying out aerobic physical exercise interventions for the purpose of glycemic control.

\section{ARTICLE HISTORY}

Received: December 26, 2019

Accepted: December 31, 2019

\section{KEYWORDS}

Physical exercise; glycemic control; diabetes mellitus

\section{CONTACT}

Yulia Kurniawati

$\triangle$ yulia.kurniawati-

2018@fkp.unair.ac.id

$\equiv$ Faculty of Nursing, Universitas

Airlangga, Surabaya, Indonesia

Cite this as: Kurniawati, Y., Baridah, H. A., Kusumawati, M D., \& Wabula, I. (2019). Effectiveness of Physical Exercise on the Glycemic Control of Type 2 Diabetes Mellitus Patients: A Systematic Review.Jurnal Ners, 14(3si), 199-204. doi:http://dx.doi.org/10.20473/jn.v14i3(si).17059

\section{INTRODUCTION}

T2DM is one of the main causes of increasing global health morbidity and mortality for $80-90 \%$ of all diabetes cases(Dixit, Maiya, \& Shastry, 2017). The increasing prevalence of T2DM is followed by some of the most influential factors such as age, obesity and a sedentary lifestyle (Lazarevic et al., 2006). The factors that affect the increase of T2DM over a long period of time leads to a variety of abnormalities in various organs, including microvascular, macrovascular, neurological and infectious complications (A, Najafipoor, Aliasgarzadeh, Niafar, \& Mobasseri, 2012).

The World Health Organization (WHO) and the International Diabetes Federation (IDF) reported that the number of patients with diabetes worldwide was projected to increase to more than 300 million people in 2025 and 366 million by 2030 . This is up from 171 million in 2000 (Animaw \& Seyoum, 2017). Different associations such as the American Diabetes Association (ADA), the American College of Physicians (ACP) and the International Diabetes Federation (IDF) assumed that the goal of glycemic control was to decrease the HbA1c level, as shown by the epidemiology analysis where each decrease by $1 \%$ in $\mathrm{HbA} 1 \mathrm{c}$ is associated with a $14 \%$ reduction in the risk of myocardial infarction (MI), a $21 \%$ reduction in mortality associated with T2DM and a $37 \%$ reduction in microvascular complications (A et al., 2012).

T2DM is caused by insulin resistance which affects the process of carbohydrate metabolism. This is because glucose transporters in cells or GLUT-4 can 
go to the plasma membrane if the corresponding insulin present. Insulin is a hormone made up of small proteins produced from the beta cells of the pancreas' islets of Langerhans and it has an important role in saving energy (Fabricio, Chango, Cezar, \& Mathias, 2016). Blood glucose level and HbA1c decreased rapidly and significantly after physical exercise (Bruce, Kriketos, Cooney, \& Hawley, 2004).

Physical exercise as an intervention to maintain glycemic control in T2DM is widely used and it has been frequently reported on to date. Many studies have focused on the effect of physical exercise in T2DM related to its actions, laboratory parameters and organ damage (Thent, Das, \& Henry, 2013). The aim of the present study was to search and review the findings from the randomized or non-randomized scientific published literature studies focusing on the T2DM patients' used types of exercise and their effect on glycemic control.

\section{MATERIALS AND METHODS}

\section{Searching strategy}

This study employed a systematic review on the effectiveness of the physical exercise for glycemic control done by T2DM patients. A comprehensive literature search was conducted using the ScienceDirect, ProQuest, Scopus, and Pubmed journal databases. This study began with determining the topic, searching for original articles and seeing if they matched with the inclusion criteria. The keywords used were type 2 diabetes mellitus, physical exercise, glycemic control, blood glucose and HbA1c.

\section{Inclusion and exclusion criteria}

The inclusion and exclusion criteria used for this study have been presented in Table 1 .

\section{Data extraction and quality assessment}

The title, abstract and the article were reviewed independently. The information was taken from each study using a collection form that consisted of the authors, the date of the study, the population, the exercise type, the outcome measures, the study design and the duration of the intervention and its intensity. The quality assessment for each selected study was conducted using the PRISMA method.

\section{RESULTS}

The results of the data search identified 1145 relevant studies, but 885 studies were excluded after the title and abstract analysis. Therefore, 260 full-text articles were assessed for eligibility after excluding 155 duplicates. In the final stage of the eligibility assessment, 141 articles were excluded and the remaining 14 studies were included in this review. A flow diagram of the PRISMA method of search and selection has been shown in Figure 1.

All of the 14 selected studies were published in English. The population was T2DM patients and the majority were published after 2004. All of the participants were aged between 18 years and 70 years old without complications. Three studies used female participants only and 11 studies used mixed participants. All of the participants were people with diabetes mellitus without insulin dependence.

The interventions that were used were aerobic exercise, resistance exercise and a combination of exercises that were both aerobic and resistance. Four studies used an aerobic only intervention. One study used a resistance only intervention. Four studies used a combination of aerobic and resistance exercises. Four studies used an aerobic exercise, in addition with tension and combination exercises. One study used a combination of exercises. The intensity of physical exercise ranged from 2 to 3 times a week for 30 to 60 minutes. The intervention was targeted at reducing HbA1c and glucose level.

Samples for the examination of blood sugar and $\mathrm{HbA} 1 \mathrm{c}$ were obtained both before exercise and after the administration of the intervention. The length of the re-examination of the blood glucose levels and HbAlc varied. All of the results of the study stated that aerobic and resistance studies gave significant results for glycemic control, blood sugar levels and HbA1c. Aerobic was the most widely used and modest exercise used to maintain glycemic control. The main characteristics of the included studies have been summarized in Table 2 .

\section{DISCUSSION}

The previous study pointed that there were 3 types of physical exercise; aerobic exercise, resistance exercise and flexibility and balance exercise. These can be done by the T2DM patients as an intervention for glycemic control (Colberg et al., 2016). Another study also stated that aerobic exercise was the most commonly done for maintaining glycemic control and resistance exercise was number two (Services, 2018). The study's result before was related to the results of the current study in that aerobic exercise, resistance exercise and a combination of aerobic and resistance exercise were the most common types of physical exercise used for maintaining glycemic control respectively. Compared with supervised aerobic or supervised resistance exercise alone, combined exercise showed there to be more of an improvement in HbA1c levels.

Aerobics is a form of exercise that involves the repeated and continuous movement of large muscle groups. Aerobic activities include walking, cycling, jogging, and swimming (T. et al., 2018). Aerobic exercises consist of many different types of exercise. Exercise is performed at moderate levels of intensity, so they can be undertaken for extended periods of time that maintain an increasing heart rate. Activities such as cycling, swimming, jogging, rowing, crosscountry skiing and aerobic dancing require oxygen to produce ATP (Adenosine Tri-Phosphate). Aerobic exercise improves oxygen consumption and it also increases the functioning of the cardiovascular and respiratory systems (Thent et al., 2013). 
Table 1. Inclusion and exclusion criteria

\section{Inclusion criteria}

1. The study design specifically evaluated the effect of physical exercise on glycemic control such as HbA1c and glucose level

2. This study focused on T2DM patients

3. Studies that were published in English

4. The study had one of the following study designs: randomized controlled trial, non-randomized controlled trial and a before-after trial
1. Studies that evaluate the effect of physical exercise on other chronic diseases

2. Studies that evaluate the effect of physical exercise on children or mothers with gestational diabetes

3. Patient with complications or another disease

Table 2. Summary of the main characteristics of the included studies

\begin{tabular}{|c|c|c|c|c|c|}
\hline Year & Sample Size & Type of Exercise & $\begin{array}{l}\text { Intensity of } \\
\text { Exercise }\end{array}$ & Finding/ conclusion & Refe-rence \\
\hline 2004 & 9 & $\begin{array}{l}\text { Combination (aerobics and } \\
\text { resistance) }\end{array}$ & $\begin{array}{l}2 \text { times/week, } 16 \\
\text { weeks }\end{array}$ & HbA1c significantly reduced & $\begin{array}{l}\text { (Tokmakidis, Zois, } \\
\text { \& Touvra, 2004) }\end{array}$ \\
\hline 2007 & 251 & $\begin{array}{l}\text { Aerobics, resistance, } \\
\text { combination (aerobics and } \\
\text { resistance) }\end{array}$ & $\begin{array}{l}3 \text { times/week, } 22 \\
\text { weeks }\end{array}$ & $\begin{array}{l}\text { HbA1c showed a significant } \\
\text { reduction in the } 3 \text { types of } \\
\text { exercise }\end{array}$ & (Sigal et al., 2007) \\
\hline 2009 & 20 & Aerobics and resistance & $\begin{array}{l}4 \text { times/week, } 16 \\
\text { weeks }\end{array}$ & $\begin{array}{l}\text { Both exercise modes have a } \\
\text { positive effect on glycemic } \\
\text { control }\end{array}$ & (Zois et al., 2009) \\
\hline 2010 & 60 & Aerobics and resistance & $\begin{array}{l}3 \text { times/week, } 50 \\
\text { minutes, } 8 \text { week }\end{array}$ & $\begin{array}{l}\text { Resistance exercise has similar } \\
\text { effects to aerobic exercise in } \\
\text { terms of reducing HbA1c }\end{array}$ & (Ng et al., 2010) \\
\hline 2011 & 48 & $\begin{array}{l}\text { Aerobics, resistance and } \\
\text { combination (aerobics and } \\
\text { resistance) }\end{array}$ & $\begin{array}{l}3 \text { times/week, } 60 \\
\text { minutes, } 12 \text { week }\end{array}$ & $\begin{array}{l}\text { Exercise training has a positive } \\
\text { effect on the glycemic } \\
\text { parameter }\end{array}$ & (Luiza et al., 2011) \\
\hline 2012 & 13 & Aerobics & 60 minutes, 7 days & $\begin{array}{l}\text { Aerobics reduced blood } \\
\text { glucose }\end{array}$ & (Mikus et al., 2015) \\
\hline 2012 & 60 & $\begin{array}{l}\text { Aerobics and resistance, } \\
\text { combination (aerobic and } \\
\text { resistance, control) }\end{array}$ & $\begin{array}{l}3 \text { times/week, } 60 \\
\text { minutes, } 52 \text { weeks }\end{array}$ & $\begin{array}{l}\text { The mean HbA1c showed a } \\
\text { significant reduction in the } \\
\text { training groups. All training } \\
\text { groups improved in terms of } \\
\text { postprandial glucose, blood } \\
\text { pressure, V02max and } \\
\text { muscular percentage. }\end{array}$ & $\begin{array}{l}\text { (Najafipour et al., } \\
\text { 2017) }\end{array}$ \\
\hline 2012 & 30 & Aerobics & $\begin{array}{l}3 \text { times/week, } 50 \\
\text { minutes, } 8 \text { weeks }\end{array}$ & $\begin{array}{l}\text { Aerobics significantly reduced } \\
\text { HbA1c concentration }\end{array}$ & (No Title, 2012) \\
\hline 2015 & 30 & Aerobics and resistance & $\begin{array}{l}50 \text { minutes, } 6 \\
\text { weeks }\end{array}$ & $\begin{array}{l}\text { Both exercises reduced HbA1c } \\
\text { and blood glucose significantly }\end{array}$ & $\begin{array}{l}\text { (Farias, Santos- } \\
\text { lozano, Urra, \& } \\
\text { Cristi-montero, } \\
\text { 2015) }\end{array}$ \\
\hline 2016 & 20 & Aerobics and resistance & 30 minutes, 7 days & $\begin{array}{l}\text { The glycemic response did not } \\
\text { differ between the exercise } \\
\text { modes }\end{array}$ & $\begin{array}{c}\text { (Brett, Stephen, } \\
\text { Richard, \& Benson, } \\
\text { 2016) }\end{array}$ \\
\hline 2016 & 20 & Aerobics & $\begin{array}{l}3 \text { times/week, } 8 \\
\text { weeks }\end{array}$ & $\begin{array}{l}\text { Aerobics significantly reduce } \\
\text { HbA1c and blood glucose }\end{array}$ & $\begin{array}{l}\text { (Mahmoudnejad, } \\
\text { 2016) }\end{array}$ \\
\hline 2016 & 52 & $\begin{array}{l}\text { Aerobics and resistance, } \\
\text { combination (aerobics and } \\
\text { resistance) }\end{array}$ & $\begin{array}{l}3 \text { times/week, } 10 \\
\text { weeks }\end{array}$ & $\begin{array}{l}\text { Blood glucose significant } \\
\text { reduce on three type exercise }\end{array}$ & $\begin{array}{c}\text { (Siavoshy \& } \\
\text { Heidarianpour, } \\
\text { 2017) }\end{array}$ \\
\hline 2017 & 65 & Aerobics & $\begin{array}{l}3 \text { times/week, } 8 \\
\text { years }\end{array}$ & $\begin{array}{l}\text { Aerobics reduced HbA1c } \\
\text { significantly }\end{array}$ & (A et al., 2012) \\
\hline 2018 & 60 & Resistance & $\begin{array}{l}3 \text { times/week, } 30- \\
40 \text { minutes, } 12 \\
\text { weeks }\end{array}$ & $\begin{array}{l}\text { Resistance exercise } \\
\text { significantly reduced HbA1c } \\
\text { and blood glucose }\end{array}$ & (Article, 2018) \\
\hline
\end{tabular}

Resistance exercises are exercises that have to be performed against resistance (Facility et al., 2015). Resistance exercise includes exercises with free weights, weight machines, body weights or elastic resistance bands. Unlike aerobic exercise, resistance exercises rely on the equipment used (Colberg et al., 2016).

Diabetes mellitus is a chronic endocrine disorder that needs definite treatment. Several complications are associated with diabetes and a lack of treatment can result in a life-threatening condition. Many researchers have explained that exercise played a crucial role in maintaining T2DM glycemic control. Exercise not only maintained glycemic control but it also improved their insulin sensitivity and lessened the diabetes-associated complications such as cardiovascular damage, which is considered to be one of the major complications (Services, 2018). Based on the past data, the present systematic review has 


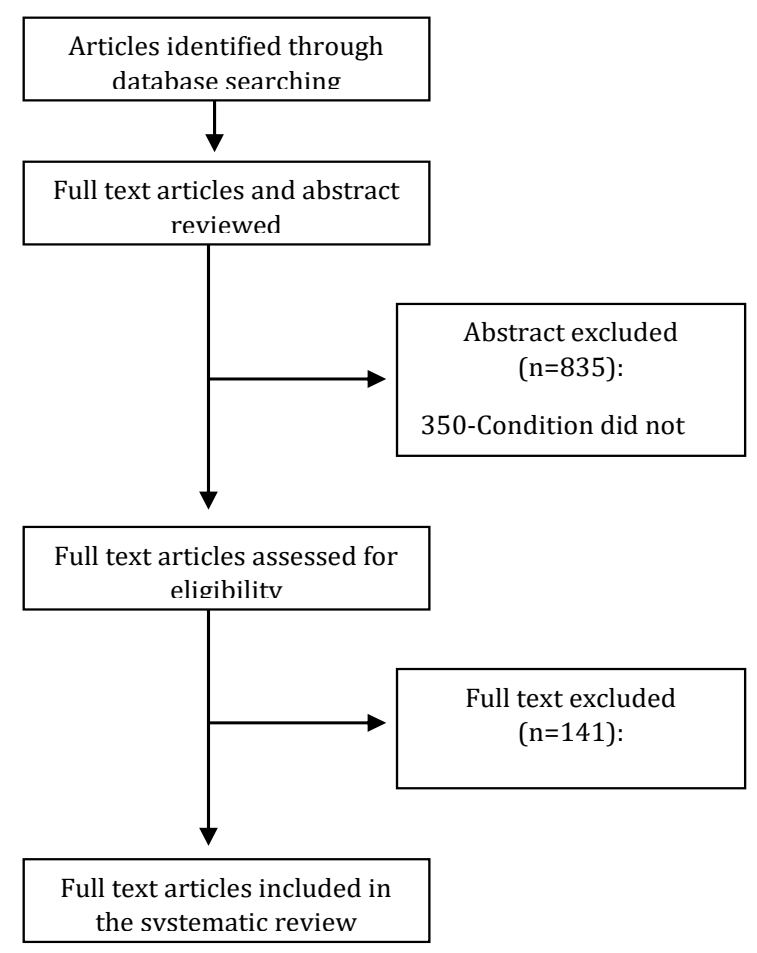

Figure 1. Flow diagram of the search and selection article process

summarized the extent and types of exercise conducted among the T2DM population.

The current systematic review revealed that physical exercise can be used as an intervention for maintaining glycemic control in T2DM. Aerobic was mostly done, followed by resistance or a combination of exercises. The fact that has to be of concern was that resistance exercise depends on the use of equipment. It could be costly and proper supervision is needed (Thent et al., 2013). Many other aspects have to be concerned with related to resistance exercises such as the knowledge of exercise, the economic aspect of exercise and the sustainability of the exercise(Training, The, \& Of, 2006). On the other hand, aerobic exercise is devoid of using equipment (Segal et al., 2018).

In this systematic review, the authors reviewed 14 research articles about physical exercise (aerobics, stretching, and a combination of aerobics and stretching) as it relates to glycemic control (blood sugar and Hba1c). The result of this review were the same as the previous study, in that aerobics significantly reduce blood glucose and $\mathrm{Hba} 1 \mathrm{c}$ through increased insulin sensitivity (Harrison, Shields, Taylor, \& Frawley, 2016). During exercise, muscle contraction stimulates an increase in AMPK activity (AMP-activated protein kinase). This activation then stimulates GLUT4 translocation into the cell membrane, thereby increasing the glucose uptake (Bird \& Hawley, 2017). In T2DM, there are deficiencies in the insulin receptors which results in impaired glucose uptake and GLUT4 translocation. However, exercise therapy could restore the defects of insulin by providing GLTU4 translocation (Bird \& Hawley, 2017).

The provision of aerobic exercise in terms of evidence and theory can reduce blood sugar and HbA1c levels. This was in accordance with the systematic results of this review, in that the most common intervention that was significant at reducing sugar levels and HbA1c was aerobics. In theory, there were more optimal and significant exercises which reduced the blood sugar levels and $\mathrm{HbA1c}$ and it is recommended by the ADA and the American College of Sports Medicine that these are used in combination rather than just aerobics (Activity, 2004). This could be done through two mechanisms. Increasing insulin sensitivity is a result of exercise-specific adaptations. Increased lean body mass (hypertrophy) is associated with resistance training, which contributes to increased glucose disposal. The problem with the authors when conducting the systematic review was that there has been only a small amount of research evaluating the benefits of aerobic combination training and resistance in the diabetic population.

Resistance exercise developed proper glucose control and less insulin resistance among the T2DM patients. Resistance exercises are an exercise that has to be performed against resistance. Examples of resistance exercises include weight lifting. Unlike aerobic exercise, resistance exercises rely on equipment. Similar to aerobic exercise, resistance exercises are useful therapeutic tools in the management of T2DM. In addition, it was also proven to be safe and efficacious for the elderly insulin resistant diabetic patients. Resistance exercise has been reported to enhance insulin sensitivity, daily energy expenditure and quality of life. Furthermore, resistance training has the potential to increase muscle strength, lean muscle mass and bone mineral density, which could enhance both functional status and glycemic control.

The schedule of carrying out exercises for between 30 - 60 minutes 3 times/week was reasonable; this consisted of 1 hour of physical exercise $3 x /$ week to reduce the capillary glucose level. At least 150 minutes/week of physical activity and dietary changes resulting in a weight loss of $5 \%-$ $7 \%$ is recommended to prevent or delay the onset of T2DM in populations at high risk and in those with pre-diabetes. Not allowing more than 2 days to elapse between exercise sessions is recommended to enhance insulin action (Services, 2018).

The limitation of this study was the variation of the intervention's duration. Two studies had an intervention duration that was for 7 days. The other studies were done over more than 8 weeks

\section{CONCLUSION}

The present systematic review revealed the effectiveness of physical exercise on glycemic control. From the published data, it can be concluded that exercise-based research on a schedule of 3 times a week for 60 minutes per session over 2 months was 
widely used and significant at reducing blood glucose and hemoglobin A1c (HbA1c). This systematic review could be used as evidence when carrying out aerobic physical exercise interventions for the purpose of glycemic control.

\section{REFERENCES}

A, A. Y., Najafipoor, F., Aliasgarzadeh, A., Niafar, M., \& Mobasseri, M. (2012). EFFECT OF AEROBIC EXERCISE , RESISTANCE TRAINING OR COMBINED TRAINING ON GLYCAEMIC CONTROL AND CARDIO - VASCULAR RISK FACTORS IN PATIENTS WITH TYPE 2 DIABETES. 135-143. https://doi.org/10.5604/20831862.990466

Activity, P. (2004). Physical Activity / Exercise and Diabetes. 27.

Animaw, W., \& Seyoum, Y. (2017). Increasing prevalence of diabetes mellitus in a developing country and its related factors. 1-11.

Article, 0. (2018). Home-Based Resistance Training Improves Glycemic Control and Body Fat Content in Patients with Type 2 Diabetes Mellitus: Experience from a Tertiary Care Hospital in Sri Lanka. 1(1), 14.

Bird, S. R., \& Hawley, J. A. (2017). Update on the effects of physical activity on insulin sensitivity in humans. (3), 1-26. https://doi.org/10.1136/bmjsem2016-000143

Brett, A., Stephen, A. G., Richard, R. B., \& Benson, M. A. C. (2016). Ac ce t. Journal of Science and Medicine in

Sport.

https://doi.org/10.1016/j.jsams.2016.01.004

Bruce, C. R., Kriketos, A. D., Cooney, G. J., \& Hawley, J. A. (2004). Disassociation of muscle triglyceride content and insulin sensitivity after exercise training in patients with Type 2 diabetes. 23-30. https://doi.org/10.1007/s00125-003-1265-7

Colberg, S. R., Sigal, R. J., Yardley, J. E., Riddell, M. C., Dunstan, D. W., Dempsey, P. C., ... Tate, D. F. (2016). Physical Activity / Exercise and Diabetes: A Position Statement of the American Diabetes Association. 39(November), 2065-2079. https://doi.org/10.2337/dc16-1728

Dixit, S., Maiya, A., \& Shastry, B. A. (2017). Effect of moderate-intensity aerobic exercise on glycosylated haemoglobin among elderly patients with type 2 diabetes \& peripheral neuropathy. (January), 129132. https://doi.org/10.4103/ijmr.IJMR

Fabricio, G., Chango, A., Cezar, P., \& Mathias, D. F. (2016). Environmental Contaminants and Pancreatic Beta-Cells. 8(3), 257-263.

Facility, C. B., Inan, Z., Depkes, Gurgand, M., Afsa, C., Briant, P., ... World Health Organisation. (2015). NIH Public Access. Sleep, 4(1), 213-223.
https://doi.org/10.1086/513446.Iijima

Farias, T. Y., Santos-lozano, A., Urra, P. S., \& Cristimontero, C. (2015). Effects of training and detraining on glycosylated haemoglobin , glycaemia and lipid profile in type-II diabetics. 32(4), 1729-1734. https://doi.org/10.3305/nh.2015.32.4.9341

Harrison, A. L., Shields, N., Taylor, N. F., \& Frawley, H. C. (2016). Exercise improves glycaemic control in women diagnosed with gestational diabetes mellitus: a systematic review. Journal of Physiotherapy, 62(4), 188-196. https://doi.org/10.1016/j.jphys.2016.08.003

Lazarevic, G., Antic, S., Cvetkovic, T., Vlahovic, P., Tasic, I., \& Stefanovic, V. (2006). A physical activity programme and its effects on insulin resistance and oxidative defense in obese male patients with type 2 diabetes mellitus. 583-590.

Luiza, M., Pereira, M., Neves, V., Oliveira, D., Maria, N., Ferreira, L., ... Geloneze, B. (2011). The effects of aerobic, resistance, and combined exercise on metabolic control, inflammatory markers , adipocytokines, and muscle insulin signaling in patients with type 2 diabetes mellitus. Metabolism, 60(9), 1244-1252. https://doi.org/10.1016/j.metabol.2011.01.006

Mahmoudnejad, M. H. (2016). Effects of aerobic training on FBS , HbA1C, Fructosamine and plasma lipid profile in male with type 2 diabetes. 27-33.

Mikus, C. R., Physiology, E., Oberlin, D. J., Physiology, E., Libla, J., Physiology, E., ... Physiology, E. (2015). HHS Public Access. 55(5), 1417-1423. https://doi.org/10.1007/s00125-012-24908.Glycaemic

Najafipour, F., Mobasseri, M., Yavari, A., Nadrian, H., Aliasgarzadeh, A., Abbasi, N. M., ... Sadra, V. (2017). Effect of regular exercise training on changes in HbA1c, BMI and VO 2 max among patients with type 2 diabetes mellitus: an 8-year trial. 1-7. https://doi.org/10.1136/bmjdrc-2017-000414

Ng, C. L. W., Goh, S., Malhotra, R., Østbye, T., Tai, E. S., Qspmmf, N., ... Usjbm, B. S. (2010). Minimal difference between aerobic and progressive resistance exercise on metabolic profile and fitness in older adults with diabetes mellitus : a randomised trial. Journal of Physiotherapy, 56(3), 163-170. https://doi.org/10.1016/S18369553(10)70021-7

No Title. (2012).

Segal, K. R., Tomas, M. B., Edano, A., Abalos, A. M. Y., Pisunyer, F. X., Blando, L., ... Pi-, F. X. (2018). Effect of exercise training on insulin sensitivity and glucose metabolism in lean, obese, and diabetic men.

Services, H. (2018). 2018 Physical Activity Guidelines 
Advisory Committee Scientific Report To the Secretary of Health and Human.

Siavoshy, H., \& Heidarianpour, A. (2017). Effects of Three Type Exercise Training Programs on FBS and HbA1C of Elderly Men with Type 2 Diabetes. 9(1), 813.

Sigal, R. J., Kenny, G. P., Boule, N. G., Wells, G. A., Prud, D., Fortier, M., ... Jaffey, J. (2007). Annals of Internal Medicine Article Effects of Aerobic Training , Resistance Training , or Both on Glycemic Control in Type 2 Diabetes.

T., R., L., B., P., B., M., M.-B., P., F., S., K., ... Ii, B. A. B. (2018). Penatalaksanaan Fisioterapi Pada Penyakit Paru Obstruktif Kronis (Ppok) Di Bbkpm Surakarta. Laporan Nasional 2013, 18(4), 213223. https://doi.org/10.1086/513446.Iijima

Thent, Z. C., Das, S., \& Henry, L. J. (2013). Role of
Exercise in the Management of Diabetes Mellitus : the Global Scenario. 8(11), 1-8. https://doi.org/10.1371/journal.pone.0080436

Tokmakidis, S. P., Zois, Æ. C. E., \& Touvra, A. (2004). The effects of a combined strength and aerobic exercise program on glucose control and insulin action in women with type 2 diabetes. 437-442. https://doi.org/10.1007/s00421-004-1174-6

Training, R., The, F. O. R., \& Of, M. (2006). FOR THE MANAGEMENT OF. 29(8). https://doi.org/10.2337/dc05-1981

Zois, C. E., Tokmakidis, S. P., Volaklis, K. A., Kotsa, K., Eleni, A. T., \& Ioannis, D. (2009). Lipoprotein pro $W$ le, glycemic control and physical $W$ thess after strength and aerobic training in post-menopausal women with type 2 diabetes. 69100. https://doi.org/10.1007/s00421-009-1104-8 